\title{
Analysis of Intermediate-scale Reservoir Heterogeneity Based on Well Exposed Outcrop Analogue within the Maastrichtian Enagi Formation, Bida Basin, North Western Nigeria
}

\author{
Goro A. I.*, Okosun E. A., Salihu H.D., Tenimu S. \\ Department of Geology, Federal University of Technology, Nigeria
}

Copyright (C) 2015 by authors, all rights reserved. Authors agree that this article remains permanently open access under the terms of the Creative Commons Attribution License 4.0 International License

\begin{abstract}
Analysis of intermediate-scale reservoir heterogeneity in a well exposed outcrop analogue of a point bar deposit within the Enagi Formation was carried out in order to reveal its reservoir dimensions. The study area is located in northern part of Bida basin, Nigeria. Three lithofacies were identified: (1) conglomerate facies interpreted as channel lag deposits; (2) epsilon and trough cross-bedded, fine to medium grained, sandstone facies interpreted as products of lateral accretion and 3D migration of subaqueous dunes in a mixed-load channel system; and (3) mudstone facies recording overbank deposits. Outcrop measurements reveal reservoir dimensions as follows: 1) bankfull channel depth of $3.9 \mathrm{~m}$; 2) bankfull channel width of $31.5 \mathrm{~m} ; 3$ ) reservoir width (meander amplitude) of $132 \mathrm{~m}$; and 4) reservoir length (meander wavelength) of $911 \mathrm{~m}$. Analysis of internal lithologic variability within the point bar deposit allowed the detection of three main internal reservoir heterogeneities. They include: a) vertical reservoir heterogeneity resulting from overall fining-up trend within the point bar deposits; b) small scale vertical heterogeneity owing to fining-up grain size within each lateral accretion unit; c) lateral reservoir compartmentalization due to mud-drapes observed on some of the lateral accretion surfaces. Information provided in this work has implications for improved computation of Stock Tank Oil in Place (STOIP) at the initial stage of exploration and in planning of well spacing during development and production stages. This work, also suggests that field measurements on outcrop analogues combined with empirical computation of reservoir dimensions provides valuable information useful at all stages of exploration and development of an oil field.
\end{abstract}

Keywords Reservoir, Fluvial, Point Bar, Heterogeneity

\section{Introduction}

A variety of scales of heterogeneity have been observed to control reservoir performance of fluvial sandstones [e.g. 1, 2, $3,4,5$, and 6]. Difficulties associated with characterizing fluvial reservoirs have also been highlighted [e.g. 7, 1]. Well exposed outcrop data provide one of the best information that may, perhaps aid proper characterization of fluvial reservoirs [8] for effective modeling purposes.

The fluvial sandstones of Bida and Enagi Formations are expected to serve as the main potential reservoir units within the Bida basin. This work therefore, aims at characterizing intermediate-scale heterogeneity of a well exposed point bar deposit within the Enagi Formation. This outcrop is situated on a road-cut located near Kawo village in Mashegu local government area of Niger state (Fig. 1).

The main objectives of the study are to:

1. Identify the lithologies and their variation within the point bar deposit.

2. Recognize the architectural elements within the point bar deposit.

3. Access heterogeneities within a single reservoir element (or sand body) which may affect fluid flow.

This unit was selected for the study because of the well exposed nature of the outcrop (not covered by vegetation), absence of structural complications such as fold and faults and good accessibility. 


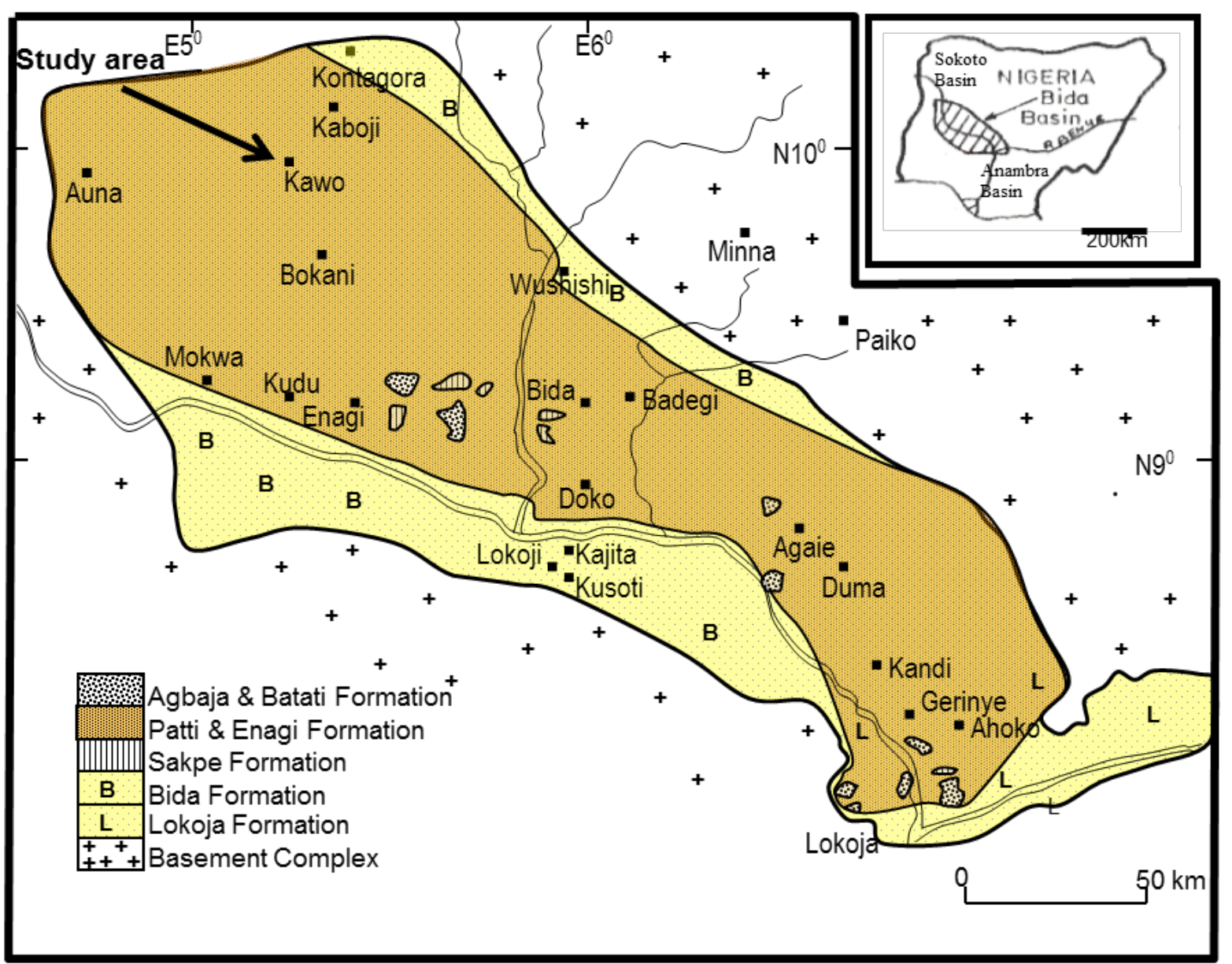

Figure 1. Simplified geological map of Bida basin showing the approximate location of the study area. (Modified from Adeleye, 1976; Obaje et al. 2013).

\section{Methodology}

Detailed mapping of the outcrop involved the documentation of lithology, grain size as well as sedimentary structures of the sediments. The well exposed nature of the outcrop allowed tracing of the two margins of the channel body. It also made possible, the measurement of the thickness of the sand body directly on the field.

The plan view geometry of the channel sand body was estimated using empirical relationships [e.g. 9, 10, 11, 12, and 13]. These relationships were based on detailed studies of modern fluvial systems.

The channel size is given by bankfull depth and width as well as their lateral extent (i.e. meander amplitude and wavelength). Reference [11] defined Bankfull channel depths as the maximum depth attained by a stream above which overbank flooding occur.

Bankfull depth was calculated from the relationship D $=D^{*} \times 0.585 / 0.9(1)$

Where $\mathrm{D}=$ original bankfull channel depth

$\mathrm{D}^{*}=$ average thickness of the point bar studied

$0.585 \& 0.9=$ correction factors for increase in depth at meander bends and reduction in original thickness due to compaction [9].
Bankfull channel width was computed using the relationship of [14] given by:

$$
\mathrm{W}=\mathrm{W}^{*} \times 1.5(2)
$$

Where $\mathrm{W}=$ bankfull channel width

$\mathrm{W}^{*}=$ average horizontal width of lateral accretion surfaces (LA) as exposed in the studied outcrop.

Reservoir length (meander wavelength) was computed using the empirical relationship of [15] given by:

$$
\lambda_{\mathrm{m}}=18\left(\mathrm{~F}^{0.53} \mathrm{~W}^{0.69}\right)
$$

Where $\lambda_{\mathrm{m}}=$ channel wavelength

$\mathrm{F}=\mathrm{W} / \mathrm{D}$ in meters $(\mathrm{W} / \mathrm{D}=$ channel width-to-depth ratio)

\section{Results}

\subsection{Lithofacies Analysis}

The road cut exposes part of the Enagi Formation sediments which are characterized by channel sandstones and overbank mudstones. The sandstones are generally light grey to whitish, fine to coarse grained with pebble sized conglomerates towards the base. The sandstones are overlain 
by mudstones, thereby constituting fining-up units. The sandstone units are occasionally stacked without intervening mudstone. Internal sedimentary structures consist of trough and planar cross bedding, epsilon cross bedding and ripple cross bedding especially towards their tops. The mudstones are generally mottled showing light grey to whitish and purple colours. Several laterally adjacent (multi-lateral) channel bodies were exposed at the outcrop and it is possible to delineate the concave-up lower boundary of one of them; this channel sand body constitutes the case study of this work.

Three lithofacies were identified within the point bar as follows.

1. Conglomerate facies (FA) - this facies overlies the concave-up basal erosional boundary of the point bar and consists of $10-15 \mathrm{~cm}$ thick unit of sub-angular to sub-rounded quartz gravels set in a matrix of fine to coarse sands (Fig. 5A \& B). It appears massive and is directly overlain by the FB facies (Fig. 3A).

2. Sandstone facies (FB) - this facies consists of epsilon cross bedded fine to medium grained sandstones (Fig. 5B \& C). They are trough-cross bedded in part. The maximum thickness of this unit around the middle of the point bar deposit is $6 \mathrm{~m}$. The lower $1.3 \mathrm{~m}$ display pebble lenses between the cross beds. Fining-up grain size profile is characteristic with the uppermost $1.5 \mathrm{~m}$ displaying alternation of very fine to fine sands and silt -clay laminae (Fig. 2). This part also shows ripple-cross lamination. The epsilon cross bedded portion may be up to $3 \mathrm{~m}$ thick (Fig. 3A, B, \& C). Other sedimentary structures include lateral accretion surfaces (LA) which sometimes run from nearly the top to the base of the sandstone unit (Fig. 3A, B, E and 4C, D \& E). Small scale fining-up of grain size was also observed within sediments that occur between the LA surfaces. Some of the LA surfaces are mud draped (Fig. 3E).

3. Mudstone facies FC - this facies consists mainly of silty mudstones (Fig. 2; Fig.3F; Fig. 5C \& D). It displays light grey to white colour with mottled texture. It has a tabular geometry and is top truncated by the erosional base of the overlying channel unit.

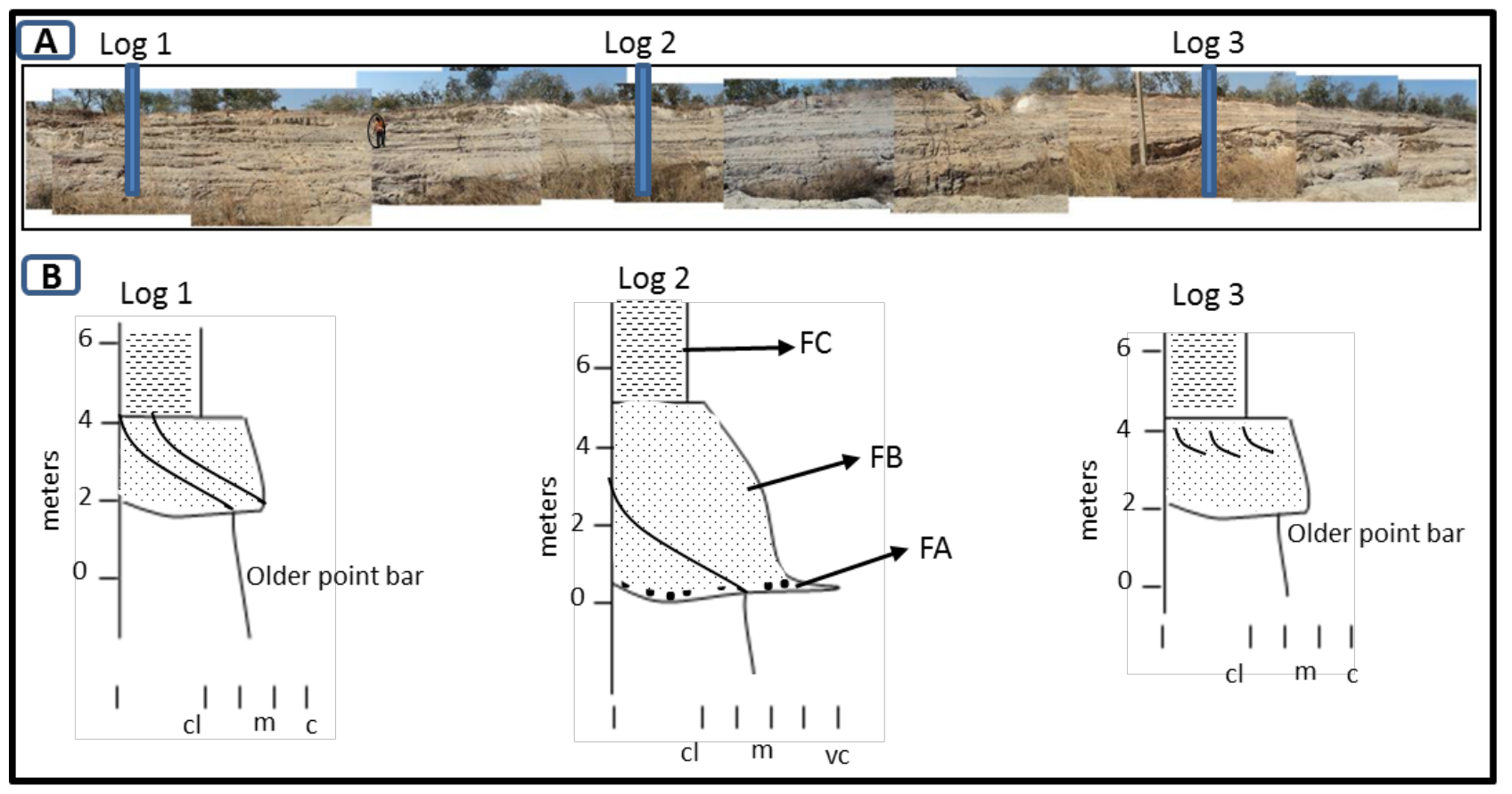

Figure 2. (A) Stacked pictures showing panoramic view of the studied point bar outcrop and positions where graphic logs were constructed; (B) Graphic logs illustrating the lithology and sedimentary structures of the studied section. 


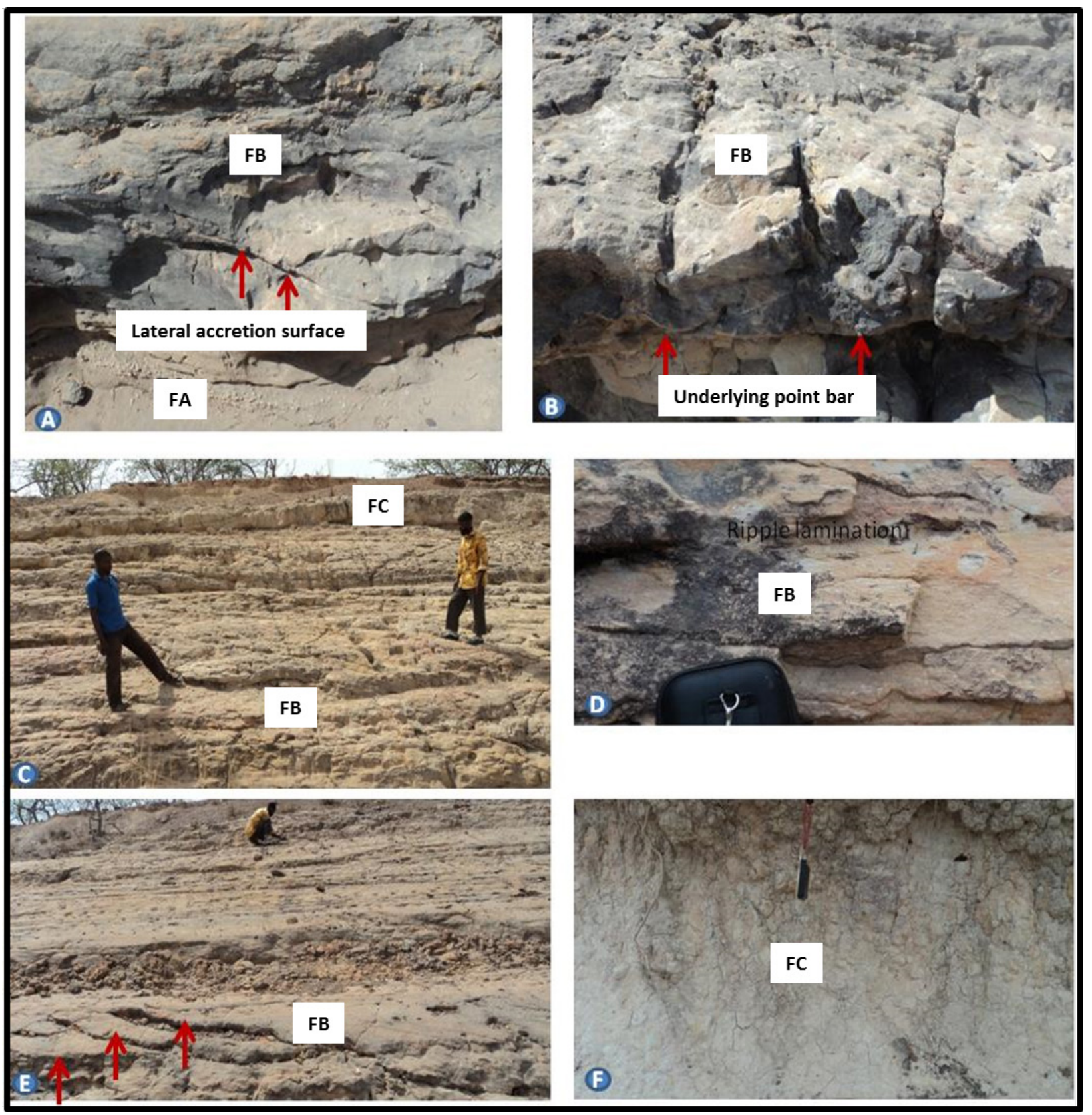

Figure 3. Outcrop pictures showing some of the characteristic features of the studied point bar. [A]conglomerate facies (FA) at the base of the channel unit overlain by sandstone facies (FB); note lateral accretion surface towards the middle part of the picture as indicated by arrows [B] close-up view showing epsilon-cross bedding and erosional surface separating the studied unit from an older point bar unit below [C] large-scale nature of epsilon-cross bedding; the two geologists are standing on lateral accretions surfaces running from the northwest to the south east of the picture [D] ripple lamination towards the upper part of the sandstone facies (FB); [E] FB showing three mud-draped lateral accretion surfaces as indicated by the arrows [F] light grey, mottled mudstones of facies $\mathrm{C}$. 


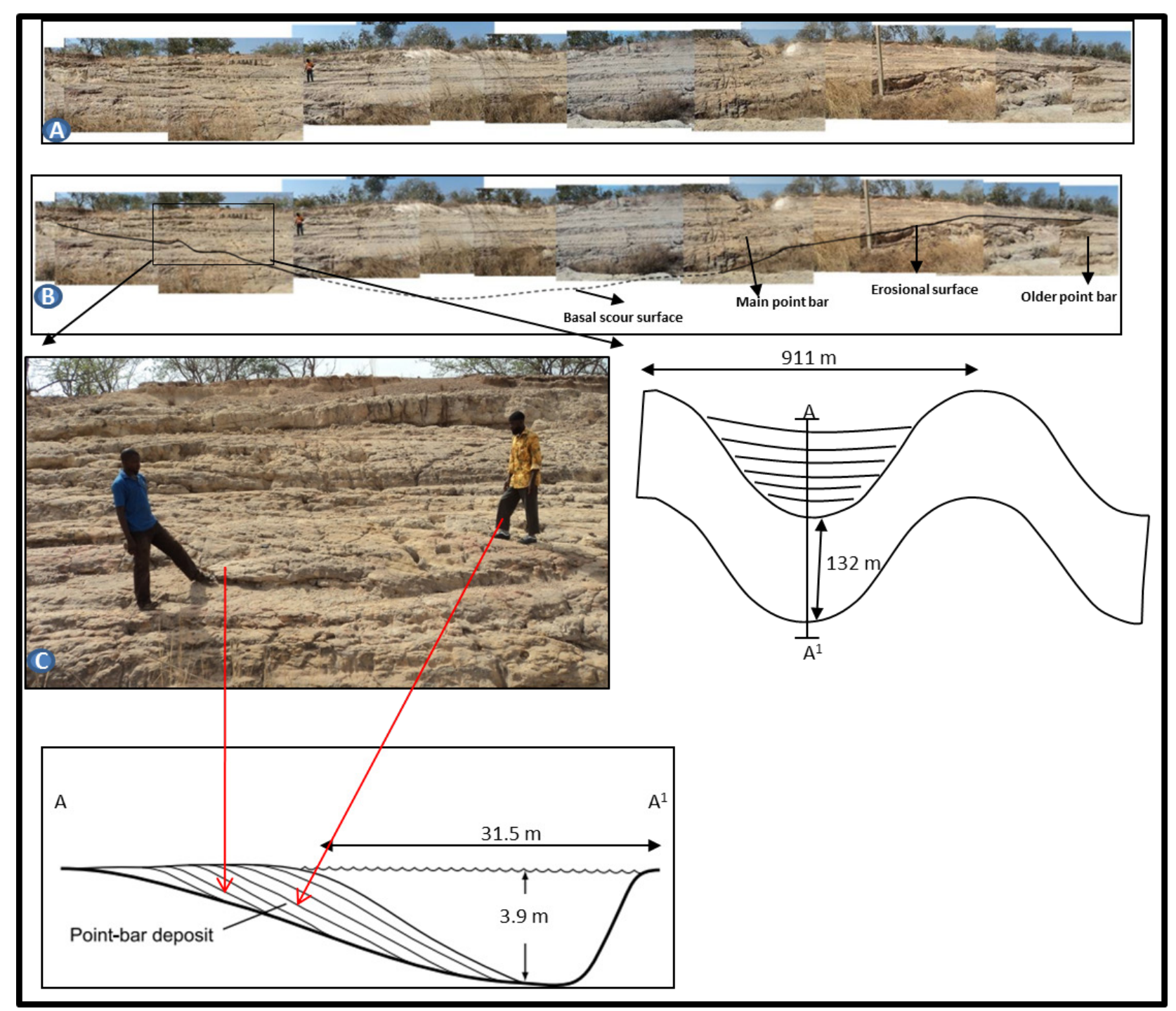

Figure 4. Pictures and sketches showing $[\mathrm{A}]$ un-interpreted photomosaic of the studied point bar $[\mathrm{B}]$ interpreted picture illustrating the concave-up channel outline of the point bar [C] large scale lateral accretion surfaces [D] plane view geometry of the point bar and its lateral dimensions [E] cross-sectional view of the point bar indicating maximum channel depth and width. 

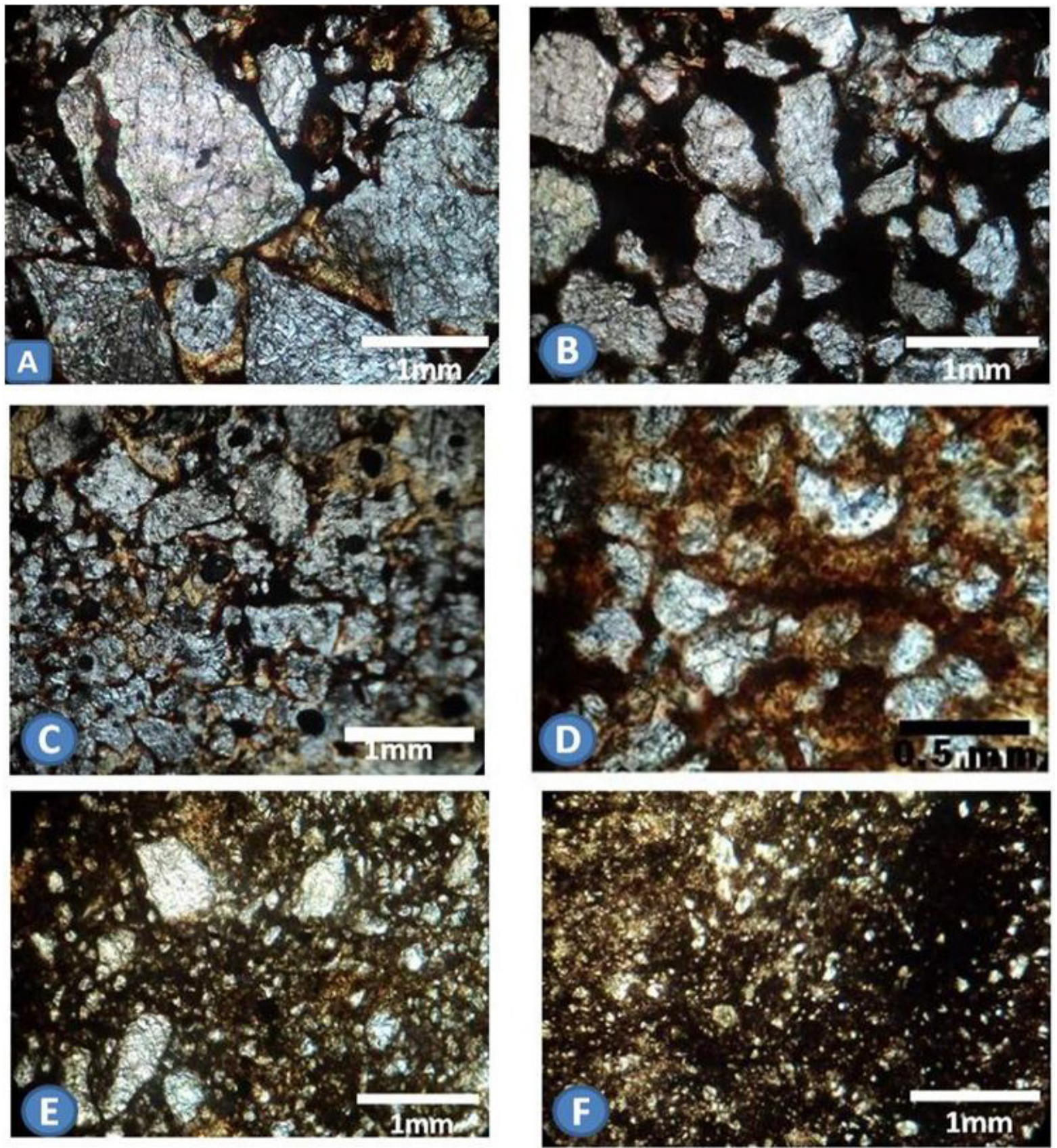

Figure 5. Photomicrographs showing $[A] \&[B]$ facies A sediments displaying coarse grained texture; $[\mathrm{C}] \&[\mathrm{D}]$ facies $\mathrm{B}$ exhibiting fine to medium grained texture; $[\mathrm{E}] \&[\mathrm{~F}]$ facies $\mathrm{C}$ showing silt to muddy texture. Note: Generally, the sediments do not show compaction features, the weathered nature of the outcrop samples made assessment of cements difficult.

\subsection{Architectural Elements}

Two architectural elements are delineated based on the lithology and geometry of the lithofacies. The FA and FB facies define channel element and the FC shows typical features of overbank element $[2,1]$.

\subsubsection{Channel Element}

It has a sharp concave-up base (lens shaped, as outlined in Figure 4B) and a flat upper boundary. The fining upwards from the conglomerates (FA) through fine to medium grained sandstone part (FB) to the rippled finer top of this element is a consequence of deposition due to velocity decrease from the base to the top of fluvial channels $(2,16$, 17]. The FA record deposition of coarse material on the channel floor while the lateral accretion surfaces record successive increments in the lateral growth of the channel and the trough-cross beds represent migration of subaqueous dunes $(2,16,18,17]$. Based on the orientation of the lateral accretion surfaces, the channel is inferred to be oriented to the north east.

\subsubsection{Overbank Element}

This element is formed by the mudstones of FC facies and 
is interpreted to record vertical aggradation in flood plain environment $[2,16]$. It is averagely $1.5 \mathrm{~m}$ thick.

\subsection{Outcrop Reservoir Dimensions}

Field measurements reveal an average thickness (D*) of 6 $\mathrm{m}$ for the point bar. This yields a bankfull channel depth of $3.9 \mathrm{~m}$ using equation 1 [11]. Average horizontal width of the lateral accretion surfaces was $21 \mathrm{~m}$ from which the bankfull channel width of $31.5 \mathrm{~m}$ was computed using equation (2). A reservoir width of $132 \mathrm{~m}$ was measured directly from the outcrop because the lateral pinch out at the two margins of the channel deposit could be delineated. A reservoir length of $911 \mathrm{~m}$ was worked out using equation (3) from the computed bankfull reservoir width (W) and bankfull reservoir depth (D).

\section{Discussion}

\subsection{Interpretations}

Point bars are known to serve as good reservoir rocks in many sedimentary basins. They are mostly associated with meandering river channel systems either in fluvial settings, tidally influenced channels or estuary settings [16-18]. Examples of well-studied point bar deposits include the modern Mississippi river point bars [e.g. 19] and tidally influenced, fluvial to estuary deposits of McMurray Formation [20], which is a hydrocarbon bearing ancient deposit.

Six levels of reservoir heterogeneity were recognized for the meandering river deposits of Mississippi river [21], which is often used as a classical modern analogue. The levels are: 1) meander belt; 2) meander scroll; 3) channel point bar and splay; 4) lobe sheet; 5) bedding unit; and 6) laminae. The present work investigated reservoir heterogeneity at Level (3), which corresponds to the scale of a single reservoir unit. Heterogeneities at this level can be caused by facies distribution, grain size and sorting as well as variation in the lithology [22-24].

Based on the grain size of the identified lithologies, the cross-bedded sandstone facies (i.e. FB) are expected to be the best reservoir intervals due to their thickness. Although permeability is expected to be higher in the generally, coarser, lag deposits (FA). The heterogeneities inherent in the results of this study includes the following: a) vertical reservoir heterogeneity resulting from overall fining upwards trend within the point bar deposit; b) small scale vertical heterogeneity due to fining-up grain size within each lateral accretion unit; c) lateral reservoir compartmentalization may result from mud drapes seen on some of the lateral accretion surfaces (Fig. 3E).

\subsection{Implications for Reservoir Studies}

Characterization of lithology as well as paleochannel width and thickness of point bar deposits is relevant to the petroleum industry given that it helps in designing the position of development wells for more efficient production of hydrocarbons from fluvial reservoirs. These parameters also aid in computing more accurate initial stock tank oil in place (STOIP) at the initial stages of exploration and appraisal whilst resource estimates are made. Information revealed by this study is difficult to almost impossible to deduce from subsurface cores and wireline log data alone due to their lateral restrictions. For these reasons the data can be used for development of more robust, predictive geological models, in similar units in the Niger delta basin or elsewhere. With the present efforts of the government of Nigeria in the exploration for hydrocarbon of the inland basins (Bida Basin inclusive); this type of information are paramount at the initial stage of exploration because they can support the generation of more robust geological models. These models are capable of revealing the possible petroleum system(s) in the Bida Basin as well as other Nigeria's inland basins in general.

\section{Conclusions}

Reconstruction of a single point bar deposit from fluvial sediments within the northern part of Bida basin was conducted using a well exposed outcrop analogue around Kawo, near Mashegu in Niger state, Nigeria. The identified lithologies consist of conglomerates facies at the base of the channel overlain by sandstones facies and capped by mudstones facies.

The sandstone facies are expected to be the main potential reservoir unit and is characterized by lateral accretion (LA) surfaces with intervening epsilon-cross bedding; trough cross bedding and ripple-cross lamination. Other sedimentary structures include fining-up grain size trend and mud drapes on LAs as well as small-scale fining-up grain size between LAs.

The progressive upwards decrease in grain size from conglomerate through sandstone to mudstone indicates gradual velocity reduction intrinsic from channel floor to the flood plain environment.

Lithological features that could influence reservoir quality of the studied interval which may influence fluid flow at intermediate-reservoir unit scale include: vertical reservoir heterogeneity arising from fining-up grain size trend and smaller scale fining-up of grain size within lateral accretion units as well as possible lateral compartmentalization due to mud-drapes on lateral accretion surfaces.

Information made available from this study is valuable at all stages of an oil field development. At the initial stage for the computation of STOIP and at development and production stage for better placement of wells in the field. Owing to difficulties and limitations in characterizing sub-surface fluvial sand bodies, the results of this work can serve as good reservoir analogue to producing fields that are fluvial in origin. 


\section{REFERENCES}

[1] A. D. Miall. Reservoir heterogeneities in fluvial sandstones: Lessons from outcrop studies: AAPG Bulletin, Vol. 72, No. 6, 682-697, 1988.

[2] A. D. Miall. Architectural-element analysis: A new method of facies analysis applied to fluvial deposits: Earth Science Reviews, Vol. 22, No. 25, 261-308, 1985.

[3] B. J. Willis. Palaeochannel reconstructions from point bar deposits: A three-dimensional perspective: Sedimentology, Vol. 36, 757-766, 1989.

[4] J. M., Sharp, S. Mingjuan, W. E. Galloway. Heterogeneity of fluvial systems; control on density-driven flow and transport: Environmental and Engineering Geosciences, Vol. 9, No. 1, 5-17, 2003.

[5] J. R. Robinson, P. J. McCabe. Sandstone-body and shale body dimensions in a braided fluvial system: Salt Wash Sandstone Member (Morrison Formation), Garfield County, Utah: AAPG Bulletin, Vol. 81,1267- 1291, 1997.

[6] D. S. Anderson. Architecture of crevasse splay and point-bar bodies of the non-marine Iles Formation north of Rangely, Colorado: Implications for reservoir description: The Mountain Geologist, Vol. 42, 109-122, 2005.

[7] R. G. Jackson. Preliminary evaluation of lithofacies models for meandering alluvial streams, in A. D. Miall, ed., Fluvial sedimentology: Canadian Society of Petroleum Geologists Memoir 5, 543-576, 1977.

[8] A. D. Miall. Reconstructing the architecture and sequence stratigraphy of the preserved fluvial record as a tool for reservoir development: a reality check: AAPG Bulletin, Vol. 7, 989- 1002, 2006.

[9] F. G. Ethridge, S. A. Schumm. Reconstructing paleochannel morphologic and flow characteristics: Methodology, limitations, and assessment, in A. D. Miall, ed., Fluvial sedimentology: Canadian Society of Petroleum Geologists Memoir 5, 703- 722, 1977.

[10] J. S. Bridge, S. D Mackey. A theoretical study of fluvial sandstone body dimensions, in S. S. Flint and I. D. Bryant, eds., The geological modelling of hydrocarbon reservoirs and outcrop analogs: International Association of Sedimentologists Special Publication 15, 213-236, 1993.

[11] M. R. Leeder. Fluviatile fining-upward cycles and the magnitude of paleochannels: Geological Magazine, Vol. 3, 265-276, 1973.

[12] J. D. Collinson. Vertical sequence and sand body shape in alluvial sequences, in A. D. Miall, ed., Fluvial sedimentology: Canadian Society of Petroleum Geologists Memoir 5, 577-586, 1978.

[13] J. C. Lorenz, D. M. Heinz, J. A. Clark, C. A. Searls. Determination of widths of meander-belt sandstone reservoirs from vertical downhole data, Mesaverde Group, Piceance Creek Basin, Colorado: AAPG Bulletin, Vol. 69, No. 5, 710-721, 1985.

[14] J. R. L. Allen. The sedimentation and paleogeography of the Old Red Sandstone of Anglesey, North Wales: Proceedings of the Yorkshire Geological Society, Vol. 35, 139-185, 1965 .

[15] S. A. Schumm. Fluvial paleochannels, in J. K. Rigby and W. K. Hamblin, eds., Recognition of ancient sedimentary environments: SEPM Special Publication 16, 98- 107, 1972.

[16] J. D. Collinson. Alluvial sediments. In: Sedimentary Environments: Processes, Facies and Stratigraphy (Ed. Reading, H.G.), Blackwell Science, Oxford; 37-82, 1996.

[17] S. Boggs. Jr. Principles of Sedimentology and Stratigraphy. Prentice Hall, Englewood Cliffs, New Jersey, 2005.

[18] Tucker, M.E. Sedimentary Rocks in the Field (3rd edition). Wiley, Chichester. 2003.

[19] R. T. Saucier. Quaternary Geology of the lower Mississippi River valley: Arkansas Archaeological Survey Research Series 6, 1974.

[20] P. A Labreque, S. M. Hubbard, J. I. Jensen, Nelsen H. Sedimentology and stratigraphic architecture of a point bar deposit, Lower Cretaceous McMurray Formation, Alberta, Canada. Bulletin of Canadian Petroleum Geology Vol. 59 No. 2, 147-171, 2011.

[21] D. W. Jordan, W. A. Pryor. Hierarchical Levels of Heterogeneity in a Mississippi River Meander Belt and Application to Reservoir Systems: Geologic Note (1), AAPG BULETTIN Vol. 76, 1601 - 1624, 1992.

[22] J. G. Richardson, D. G. Harris, R. H. Rossen, G. Van Hee. The effect of small, discontinuous shales on oil recovery: Journal of Petroleum Technology, Vol. 20, 1531- 1537, 1978.

[23] N. Tyler, R. J. Finley. Architectural controls on the recovery of hydrocarbons from sandstone reservoirs, in A. D. Miall and N. Tyler, eds., The three-dimensional facies architecture of terrigenous clastic sediments and its implications for hydrocarbon discovery and recovery: SEPM Concepts in Sedimentology and Paleontology, Vol. 3, 1-5, 1991.

[24] B. J. Willis, C. D. White, Quantitative outcrop data for flow simulation: Journal of Sedimentary Research, Vol. 70, No. 4, 788-802, 2000. 